\title{
Curatorship Paradox: Corporate Governance in Dilemma
}

\author{
Dr. Martin Dandira ${ }^{1} \quad$ Kudzanai Vere $^{2} \quad$ Munoneka Sithole $^{2} \quad$ Maxwell Chufamba $^{3} \quad$ Dr. Obert Sifile ${ }^{4}$ \\ 1.Senior Lecturer, Business Management and Entrepreneurship Department:Chinhoyi University of Technology, \\ P.Bag 7724, Chinhoyi,Zimbabwe \\ 2.D.Phil Student, Business Management and Entrepreneurship Department:Chinhoyi University of Technology, \\ P.Bag 7724, Chinhoyi,Zimbabwe \\ 3.Lecturer, Marketing and Logistics Deapartment,Namibia University of Science and Technology,P.Bag \\ 13388, Windhoek,Namibia \\ 4.Finance Director, Chinhoyi University of Technology, P.Bag 7724, Chinhoyi, Zimbabwe
}

\begin{abstract}
The Zimbabwean financial sector has witnessed financial institutions failures and placing these institutions under curatorship has been the solution. In most cases curators have not been able to bring the banks to the original position instead they have fast tracked the liquidation of these institutions. Since 2004, more than 15 financial institutions have been placed under curatorship by the Reserve Bank of Zimbabwe. Accountants have been found to be prominent appointed curators and they have been found to facilitate the liquidation of these institutions rather than resuscitating them and as a result corporate governance has been found to be in dilemma. Curatorship has been found to be a lucrative business for accountants and lawyers whose main jobs have been to facilitate the winding up of companies rather than turning them around. The costs of placing a financial institution under curator have been high to such an extent that huge sums of money have been paid which could have been channelled towards turning around it. Curators in most cases as indicated in this study have not helped financial institutions to perform better instead they have worsened it.The paper used a document review research method to show how corporate governance has been placed in dilemma by appointing accountants as curators and how they have facilitated the winding up of these institutions rather than bringing them back to position.
\end{abstract}

\section{Article Type: Discussion paper}

Keywords: curatorship, paradox, dilemma, financial institution

DOI: 10.7176/PPAR/9-9-01

Publication date:September $30^{\text {th }} 2019$

\section{Introduction}

Since 2004, more than 15 financial institutions have been placed under curatorship by the Reserve Bank of Zimbabwe. This was due to the fact that they had to meet new stringent capital requirements. Commercial banks were supposed to have $Z \$ 1$ trillion while merchant and building societies $Z \$ 750$ billion in their books. Empirical studies show that most curators have facilitated the fast demise of these institutions they have been appointed to manage. This brings us to the fact that corporate governance is being short changed by both the authorities who appoint curators and the curators. Accountants firms and lawyers have been always appointed as curators of financial institutions but the performance have not been satisfactory. A curator is roped in after a financial institution faces problems and to protect the investments of depositors, curator is sought to look for fresh capital injection and strategies to serve the financial firm. Curatorship is aimed at protecting the interests of depositors and creditors, while the curator determines the full extent of the problems faced by the financial institutions before recommending the way forward but this is not the case in most of the time.

The word "curatorship" and its close cousin "curator" evoke painful memories for a vast swath of the Zimbabwean banking public because of the loss the depositors experienced.

During the turbulence of the 2003/2004 banking crisis they featured so prominently in the public consciousness that they became part of an enduring negative stimuli often associated with that banking era. In Zimbabwe, a curatorship has never been truly embraced as the solution that it is meant to be, primarily because it is designed for an inherently unpopular purpose. Curatorship has become symbolic with financial loss in all its conceivable forms - temporary loss, permanent loss, and loss of value, loss of time and loss of momentum.

Ominously, with the exception of Royal Bank Zimbabwe Limited and Trust Bank Corporation, most financial institutions previously placed under the management of a curator are currently not in operation - at least not in their original form. Understandably, when curatorship rears its "ugly" head once more in the relatively calmer waters of 2011 — as it recently did at Renaissance Merchant Bank Limited - it is a time to be afraid for those that still bear the scars of the past and regulatory authorities to learn from the past.

\section{Literature Review}

2.1 Corporate governance and its importance

According to the Economic Commission for Southern Africa(ECA)Southern Africa Office(SRO- 
SA) Governance issues have taken centre stage in the development discourse and in particular on Africa's development agenda (Otobo, 2000). This is because most of Africa's problems have in the last forty-five years been linked to governance issues: principally the rule of law or control by the State. In this context, governance has been construed to mean political governance. This is because economic change or transformation is dependent on the willingness of the political elite to steer the economy in some preferred direction. Therefore, the poor economic performance of many States in Africa has been blamed on an inappropriate political environment, particularly poor governance. It is a well-known fact that the political environment defines the context in which economic governance and corporate governance are practised. Otobo (2000), states that the relationship between political governance, economic governance and corporate governance can be likened to concentric circles in which the political governance circle forms the outside, followed inwards by the economic governance circle, with the corporate governance circle at the centre.

Johnson and Scholes (1997) pointed out that corporate governance involves the determination of "minimum obligations of an organisation towards its various stakeholders. Corporate governance refers to the act of an organisation by senior management generally known as board of directors.Greuning and Bratanovic (2003) stated that the board is answerable to depositors and shareholders for the safeguarding of their interests through the lawful, informed, efficient, and able administration of the institution. Corporate governance can however not be associated with only one class of management in a firm. All management staff is involved in one way or another in running of the firm practise some form of corporate governance. Sheridan and Kendall (1992) observed that management is concerned with the company's operation, governance and ensuring that executives do their job properly. McGregor (2000) observed that the function of corporate governance is to lead, create and maintain structures and systems and monitor performance. How people govern depends upon their values and beliefs, their ability to make decisions, as well as their capacity to ensure effective implementations of decisions. McGregor (2000) quoting Hampel (1998) suggested that governance is the process whereby people in power make decisions that create, destroy or maintain social systems, structures and processes. However, institutionalized abuse of power is a difficult thing to deal with because of its pervasiveness (Garrant, 1997).Davis(2001) has said that there is an iron law of responsibility which states that in the long-run, those who do not use power in a manner that society considers responsible they will lose it. McGregor (2000) stated that those in power have the potential to improve or destroy the quality of lives of many people. Soros (1998) suggested that the relationship between specific groups help to maintain or create national, international or global systems, regulations and structures.

The OECD standards (Mesnard, 2005) encourage enterprises to disclose material information on:

- The financial and operating results of the company;

- Company objectives;

- Major share ownership and voting rights;

- Members of the board and key executives and their remunerations;

- Material risk factors;

- Material issues regarding employees and other stakeholders; and

- Governance structures and policies

The above discussion explicitly indicates the importance of good governance in different contexts of the society and without good governance societal problems become difficulty to eradicate.

\section{Methodology}

This paper is based on abridged cases among many of corporate governance issues pertaining to curatorship in Zimbabwe which most of the financial institutions had paid large amounts of money to curators. The aim of curatorship is to protect the interests of depositors and creditors, while the curator determines the full extent of the problems faced by the institutions before recommending the way forward but this has not been the case in the case studies under discussion below. The paper used a document review research method.

Sixteen (16) financial institutions make up the case portfolio. The study was carried out in 2011. The data collection mainly takes desk research approach and verification of facts by employers and former employees of the financial institutions of these case studies. The sixteen (16) case studies consist of financial institutions which were placed under curatorship. Judgemental sampling was used to select the cases. The technique was appropriate since more than eleven institutions were considered in the initial pool. The analysis and discussion in this paper is qualitative. Qualitative method is preferred, the qualitative descriptive case study approach was appropriate for this research because it gives detailed accounts and deeper understanding of events and processes and practices that provides a ground for critical inquiry that raises consciousness for possible steps for decisionmaking.

The study focused on financial institutions that were placed under curatorship and corporate governance issues were short changed or put in dilemma. Conclusions are presented not only on theoretical perspective but also on practical emphasis. 


\section{Findings and Discussion}

\subsection{Century Discount House Limited (CDH)}

The discount house was closed on 2 January 2004 and its Banking Licence was cancelled after a determination by The Reserve Bank that the institution was insolvent and was facing serious liquidity problems. The insolvency was a result of imprudent lending to ENG Asset Management (Private) Limited, whose holding company had acquired CDH Limited from Century Holdings Limited without regulatory approval. At the time ENG Asset Management (Private) Limited was an unsupervised entity. The discount house was later placed under liquidation, and the liquidator sued the directors of Century Discount House in their personal capacities for gross negligence in running the affairs of the institution.

\subsection{Rapid Discount House Limited}

Rapid Discount House Limited was registered as a discount house on 15 October1997. The institution was placed under curatorship on 26 April 2004, following a determination by the Reserve Bank that it was insolvent and was not operating in accordance with sound administrative and accounting practices and procedures. The capital shortfall emanated from a high volume of imprudent, unauthorized non- performing insider loans. Further, the institution had departed from its core business of money market investments and was issuing loans to companies connected to the directors and shareholders. The said loans were deliberately disguised as NCDs issued to various counterparties. Efforts by the curator to pursue new investors failed due to the level of insolvency, whilst the existing shatholdas were unwilling or unable to put up the required capital. As a result, the discount house was placed in compulsory liquidation on 1 December 2004. The liquidator has instituted proceedings against directors for negligent conduct of business in terms of Section 318 of the Companies Act [Chapter 24:03].

\subsection{Barbican Bank Limited}

Barbican Bank Limited, a wholly owned subsidiary of Barbican Holdings Limited was licensed as a commercial bank in December 2002 and commenced operations in July 2003. The Bank faced serious liquidity challenges largely emanating from the funding of sister companies such as asset management companies and group subsidiaries in South Africa as well as non performing insider loans. The bank engaged in fraudulent foreign exchange activities to fund operations of foreign subsidiaries. The bank used local depositors' funds to support its operations in South Africa, London and Zimbabwe. Poor corporate governance practices were at the centre of the challenges that faced the bank. There were no separate and independent boards for each subsidiary and the holding company. In addition, there was over domineering by the Chief Executive Officer who was one of the major shareholders. The group mixed banking and non-banking business despite an earlier undertaking by management to desis from the practice after being warned of the dangers of such practice by the Reserve Bank. The bank also abused Reserve Bank liquidity support by funding non-banking activities such as purchase of shares in various counters on the stock exchange. A Corrective Order was issued to the bank on 13 January 2004, to address the identified deficiencies and irregularities. The Reserve Bank subsequently determined that the institution was insolvent and illiquid. The board and shareholders failed to resolve the challenges faced by the bank resulting in the Reserve Bank placing the institution under curatorship on 15 March 2004.The Curator confirmed that the bank was both insolvent and illiquid and hence explored possible ways to recapitalize the bank. Shareholders subsequently made half-hearted proposals which fell short of fully addressing the liquidity and solvency challenges facing the bank. In view of the above, recommendations were made to incorporate assets of the bank into Zimbabwe Allied Banking Group (ZABG) in January 2005, as part of the implementation of the Troubled Bank Resolution Framework. The Reserve Bank has extended curatorship to 28 February 2006 to facilitate finalization of outstanding issues.

\subsection{Trust Bank Corporation Limited}

Trust Bank Corporation Limited began operations in January 1996 as a merchant bank and converted its licence to a commercial bank in 2000.The bank was facing serious liquidity and solvency challenges emanating from rapid expansion without a corresponding increase in capital, as well as high levels of non- performing loans. Poor corporate governance structures, which resulted in poor asset and liability management also contributed to the bank's demise. The bank was also engaging in non-banking activities through a Special Purpose Vehicle (SPV), TMB Nominees. These challenges were a reflection of technical mismanagement which eventually unleashed cosmetic and desperate management practices. Following the findings of an onsite examination by the Reserve Bank, an independent investigation of the bank was commissioned which confirmed that the bank was facing liquidity challenges. The bank's capital deficit was a result of huge losses stemming from poor asset quality and the inhibitive cost of refinancing huge liquidity net mismatches. Various merger initiatives, with a number of local and regional investors failed to sail through, largely as a result of the huge capital deficit. Due to the incessant challenges at the bank, Trust Bank's board and management were 
restructured, by order of the Reserve Bank. In addition, the Reserve Bank appointed a full time supervisor on 20 January 2004 to monitor the situation at the bank on an on-going basis. However, the financial condition of the institution worsened as there was no tangible progress made on the re-capitalization thrust. Consequently the bank was placed under the management of a curator on 23 September 2004.In line with the Troubled Resolution Framework the assets of the bank were sold to ZABG. The altemative strategy, straight liquidation of the bank, was considered undesirable due to potential prejudice to the depositors and creditors whom curatorship is designed to protect. Trust Holdings Limited, the shareholder of Trust Bank Corporation Limited, contested the disposal of assets to ZABG by the curator. The curatorship period was extended to 28 February 2006, in order to allow for the finalization of the appeal noted by the shareholder of the bank to the Reserve Bank of Zimbabwe, against the curator's actions.

\subsection{Royal Bank Zimbabwe Limited}

Royal Bank Zimbabwe Limited commenced commercial banking operations on 8 May 2002.Royal Bank Zimbabwe Limited was placed under curatorship on 4 August 2004, after it was determined that it was facing chronic liquidity problems and was insolvent. The capital deficit was mainly attributed to non-performing loans, the bulk of which were insider loans. The bank failed to inject the required capital and liquidity to meet maturing liabilities and extinguish the Reserve Bank liquidity assistance facility. The directors engaged in malpractices which included granting of insider loans, illegal foreign currency dealing, siphoning of depositors funds and poor corporate governance practices. The Directors recapitalized the bank using depositors' funds in violation of both the Banking Act and the Companies Act. Technical mismanagement by the bank led to cosmetic management tendencies involving hiding past and current losses to buy time and remain in control while looking and waiting for solutions. Negotiations were pursued with potential investors to inject capital but these talks collapsed after due diligence exercises unearthed the true extent of the huge capital deficit and poor corporate governance practices which rendered the bank unviable. It was against this backdrop that the Reserve Bank placed the bank under curatorship. Royal Bank's assets were sold to ZABG in January 2005 after it was determined that it was the most appropriate solution compared to an outright liquidation of the bank. The Reserve Bank extended the period of curatorship for the bank from 31 December 2005 to 28 February 2006, in order to allow for the finalization of the appeal noted by the shareholders of Royal Bank, to the Reserve Bank of Zimbabwe, against the curator's decision to dispose of the bank's assets.

\subsection{Time Bank of Zimbabwe Limited}

Time Bank of Zimbabwe Limited commenced operations in May 1997. The bank was placed under curatorship on 7 October 2004 after a determination that the bank was insolvent, was not operating in accordance with sound administrative and accounting policies, and was experiencing serious liquidity challenges. The chronic liquidity challenges experienced by the bank emanated from poor corporate governance practices and weak risk management systems. All key decisions centred on one senior member of management, rendering the board ineffective. The bank engaged in schemes that involved the booking of fictitious loans in order to inflate the bank's balance sheet as well as provide an artificial basis for posting non-existent income. This cosmetic management was characterized by chronic insider manipulation and fraudulent misrepresentation. It is against this background that depositors' funds were siphoned under a well-orchestrated and calculated fraudulent intricate web of related company transactions. The period of curatorship was extended to 28 February 2006, to facilitate finalization of outstanding issues by the curator.

\subsection{CFX Bank Limited}

CFX Bank Limited was established following the merger between Century Holdings Limited and CFX Financial Services in July 2004. Prior to the merger Century Bank Limited had been operating as a commercial bank since 2001.CFX Bank was placed under curatorship on 17 December 2004, following a determination that the institution was insolvent and facing serious liquidity and profitability challenges. There were a number of underlying causes to liquidity challenges faced by the bank. There was rapid expansion through acquisition of branches disposed of by other banks using depositors' funds instead of shareholders' funds. The problems also emanated from purchasing of foreign currency on the parallel market which was not accounted for in the banks records. In addition, cosmetic management was evident as reflected by bank management who were manipulating computer generated financial statements in order to conceal accumulated and monthly losses. Management also resorted to the creation of fictitious assets in order to conceal the losses and funding gaps on illegal foreign exchange deals. The utilization of depositors' funds to acquire fixed assets further exacerbated the liquidity problems. The huge non-performing insider loans also compounded the problem. The institution was adversely affected by poor corporate governance practices, as evidenced by numerous unauthorized excesses and imprudent write-offs of interest on insider loans. The problems at the bank were compounded by inadequate capitalization. The bank's shareholders failed to come up with concrete 
recapitalisation plans. In January 2004, the bank was issued with a Corrective Order which, among other issues, required it to improve effectiveness of risk management systems, submit a plan to maintain sufficient capital, tighten controls on insider lending, and to take necessary steps to address its chronic liquidity problems. A targeted on-site examination conducted on 15 December 2004 determined that the bank was insolvent and had a huge accumulated loss. The bank's internal auditors and independent external auditors also confirmed the accumulated losses and manipulation of management accounts. As a result of these losses, the bank was found to be insolvent. These findings were subsequently corroborated by the curator's reports. In addition, the curator determined illegal dealings by counterparties on the bank's assets, inadequate capitalisation, imprudent insider dealings, illegal foreign currency dealings and ineffective risk management. The major shareholders failed to raise the funds required to recapitalize the institution. Consequently, a scheme of arrangement with creditors of CFX Bank was eventually concluded in order to salvage the bank. The said scheme involves a merger between CFX Merchant Bank Limited and CFX Bank Limited. Following debt-equity conversions, depositors and creditors are now collectively the largest shareholders in the bank. In addition to the debt-equity conversions, some shareholders have made a commitment to inject additional capital. Significant progress has been made in resuscitating the institution which is expected to reopen once all regulatory requirements have been satisfied.

\subsection{CFX Merchant Bank}

CFX Merchant Bank Limited started operating in April 2002 following acquisition of the failed Universal Merchant Bank Zimbabwe Limited.The bank was placed under curatorship on 17 December 2004 following a determination that the bank was technically insolvent and was facing liquidity problems. The liquidity problems emanated from huge exposures to the troubled CFX Bank. Exposures to CFX Bank rendered the merchant bank technically insolvent. The merchant bank also used convoluted schemes involving the transfer of depositors' funds to SPVs in order to create an illusion of meeting the deadline for Reserve Bank minimum capital requirement that had been increased to $\$ 7.5$ billion with effect from 30 September 2004.As already indicated, the merchant bank will be merged with the commercial bank.

\subsection{National Discount House Limited}

The discount house experienced severe liquidity challenges in December 2003, owing to its exposures to financial and non-financial institutions. The discount house also faced solvency problems emanating from nonperforming insider loans. In order to address the solvency challenges, NDH engaged in a two-pronged recapitalization programme involving conversion of debt into equity and a subsequent merger with a local financial services group. Notwithstanding the successful debt- equity conversions, the strategic partner pulled out at the last minute. A consortium of new shareholders has however injected new capital, and the bank will resume operations once all the regulatory requirements have been satisfied.

\subsection{Intermarket Banking Corporation Limited}

Intermarket Banking Corporation Limited commenced operations in January 2003. The bank was placed under curatorship on 12 March 2004, following a determination that the bank was in an unsafe and unsound financial condition. The Group Chief Executive and major shareholder dominated the boards of the Intermarket subsidiaries, and influenced the direction of all major transactions for his personal gain. Consequently, the board was ineffective, and management pandered to the whims of the CEO. The challenges which bedevilled the bank included imprudent risk management practices and poor corporate governance arrangements, which heavily compromised asset and liability management. Substantial loans were granted to the CEO and related parties, which loans turned out to be non-performing. The bank was an active player on the foreign exchange parallel market, and externalized most of the funds. The curator worked extensively on the restructuring of the Group, and completed a scheme of arrangement which entailed a conversion of debt in the subsidiaries to equity in the holding company, which was sanctioned by the High Court in July 2005. The bank resumed full scale operations in January 2006 following the upliftment of curatorship on 31 December 2005.

\subsection{Intermarket Discount House Limited}

Intermarket Discount House Limited commenced operations in January 1991. The discount house was placed under the management of a curator on 12 March 2004, following a determination by the Reserve Bank that the institution was facing severe solvency and liquidity problems. The institution was heavily involved in lending activities, which is non-core business for discount houses. The discount house had a huge non-performing book, which was largely linked to the CEO and related parties. Following proposals for a market solution to the problems of the Intermarket banking subsidiaries, the curator worked out a scheme which entailed the conversion of debt in the subsidiaries into equity in the holding company. To date, successes have been registered in respect of the resolution strategy, as the debt equity conversion was sanctioned by the High Court, and the 
institution is now adequately capitalized. Curatorship was uplifted on 31 December 2005, and the discount house has since resumed full scale operations.

\subsection{Intermarket Building Society}

Intermarket Building Society was placed under the management of a curator on 12 March 2004. This followed a determination that the Society was experiencing severe liquidity problems emanating from exposure to the troubled Intermarket Discount House. In resuscitating the building society, the curator worked out a scheme in terms of which the Inter-company debts within the Group were set off against the assets of the discount house, thereby addressing the liquidity problems that had led to the placement of the building society under the management of a curator. The building society commenced full operations following upliftment of curatorship on 1 August 2005.

\subsection{First National Building Society}

It was founded by two directors in the late 1990s and The duo has a combined $89.74 \%$ in the holding company.FNBS was placed under curatorship on 7 February 2003 following the arrest of the two founding directors for allegedly defrauding the society of ZW \$958 million through insider loans and squandering depositors funds on luxuries such as building expensive houses .They were arrested and later released In January Master of High Court postponed indefinitely the liquidation of FNBS to give the provisional liquidator and major shareholders time to finalise modalities aimed at reopening the society. The building society was finally liquidated.

\subsection{United Merchant Bank}

The bank was granted a licence in 1995 to start operating as a Merchant Bank. The founder of the bank was an entrepreneur with business interests in many sectors. He is known for the construction one of the world's largest tobacco sales floor. What was clear is that he did not have the experience to run a bank, and that if he had been subjected to the rigorous screening processes required of bank promoters, he would have come seriously shortfalls but he was well connected to politicians. As a banking institution, United Merchant Bank accepted deposits and paid interest rates well above the market average. He was not concerned with the profitability of the bank but rather with ensuring that he would get liquidity to launder by way of deposits. The deposits were partly used to finance personal obligations both inside and outside Zimbabwe.

United Merchant Bank was given the mandate by government to raise funds for the operations of the Cold Storage Company, a parastatal involved in beef production and sale within and outside Zimbabwe. It was to issue bills to the value of $Z \$ 413$ million. For some reason, a government guarantee was issued to the value of $\mathrm{Z} \$ 855,16$ million. He proceeded to issue an additional Z\$1,263 million worth of Cold Storage Company bills. He was able to issue as many bills as he wanted because the bills are tradable. He opened external accounts and proceeded to purchase foreign currency and transfer it to accounts outside the country. He deposited money in Botswana, South Africa and the United Kingdom. Depositors' funds were mingled with personal funds and used to acquire properties. One of the more prominent properties was a tobacco auction floor outside Harare, which became the biggest tobacco auction floor in the world.

This case also illustrates how political considerations can be used to obtain a bank licence. Ordinarily, the proprietor and promoter would not have been allowed to run a bank. When his bank was in a bad state, He blamed high-level officials for not repaying money owed to the bank. He was eventually but somewhat belatedly charged under the Serious Offences (Confiscation of Profits) Act, but died before the case could be tried. The bank was the first to be placed under curatorship and liquidated in the history of financial system in Zimbabwe.

\subsection{ReNaissance Merchant Bank (RMB)}

The bank was placed under curatorship on 3 June 2011 for six months after establishing that there was a systematic abuse of depositors' funds, a high level of non-performing insider loans and related-party exposures that included a US\$9,8 million loan to its former CEO and gross violations of banking laws and regulations. RBZ investigations established that the major shareholders were able to maintain their shareholding in the bank through elaborate schemes which involved borrowed funds and abuse of deposits. The merchant bank also bought back some of its shares using depositors' funds in violation of Section 32 of the Banking Act.

The merchant bank, which scored a first by being put under such management since the economy was formally dollarized two years ago, was also found to be technically insolvent, with a negative capital of about US\$16,7 million as at April 30,2011 and a 38\% exposure to insiders. The curatorship is in terms of Section 53 of the Banking Act. The bank is still under curatorship and it has been extended by two months to February 2012.

\subsection{ENG Capital Investment}

The asset management company was founded by two you directors from one of the university of science and 
technology in Zimbabwe. The investment company grew fast and the two directors operated as a full board. They lead a flamboyant life includes buying several top of the range vehicles and expensive life using depositors' funds. Early 2004 the company's problems began failing to pay depositors' funds on maturity. They failed to account for $\mathrm{Z} \$ 61$ billion of investors' funds. They gave themselves loans and did not pay back to the company. The two directors were arrested at the time of liquidation. They were released on bail and one of the directors skipped to USA.The company was a major shareholder of Century Bank through various investments and the board of directors of Century Bank were not aware.

Table 1:Summary of Financial Institutions placed under curatorship

\begin{tabular}{|c|c|c|c|c|c|}
\hline $\begin{array}{l}\text { Financial } \\
\text { Institution }\end{array}$ & $\begin{array}{l}\text { Year } \\
\text { registered }\end{array}$ & $\begin{array}{l}\text { Date placed } \\
\text { under } \\
\text { curatorship }\end{array}$ & Reasons for curatorship & Outcome & Curators \\
\hline $\begin{array}{l}\text { United } \\
\text { Merchant } \\
\text { Bank(UMB) }\end{array}$ & 1990 & 1998 & $\begin{array}{lr}\text { Imprudent } & \text { banking } \\
\text { practices such } & \text { insider } \\
\text { transactions } & \text { among } \\
\text { others } & \\
\end{array}$ & liquidated & $\begin{array}{l}\text { Accountant } \\
\text { KPMG }\end{array}$ \\
\hline $\begin{array}{l}\text { Century } \\
\text { Discount } \\
\text { House }(\mathrm{CDH}) \\
\end{array}$ & 1997 & 2004 & $\begin{array}{l}\text { Liquidity problems and } \\
\text { imprudent lending }\end{array}$ & liquidated & $\begin{array}{l}\text { Accountant: Tudor } \\
\text { House Consultants }\end{array}$ \\
\hline $\begin{array}{l}\text { Rapid } \\
\text { Discount } \\
\text { House(RDH) }\end{array}$ & 1997 & 2004 & $\begin{array}{l}\text { High volume of } \\
\text { imprudent, unauthorised } \\
\text { non-performing insider } \\
\text { loans }\end{array}$ & liquidated & $\begin{array}{l}\text { Accountant Ernest and } \\
\text { Young }\end{array}$ \\
\hline $\begin{array}{l}\text { First National } \\
\text { Building } \\
\text { Society(FNBS) }\end{array}$ & 1990 & 2004 & $\begin{array}{l}\text { Fraud and extended } \\
\text { periods of unchecked } \\
\text { mismanagement. }\end{array}$ & liquidated & $\begin{array}{l}\text { Accountant:: } \\
\text { Price Waterhouse }\end{array}$ \\
\hline $\begin{array}{l}\text { ENG Capital } \\
\text { Investment }\end{array}$ & & 2004 & $\begin{array}{lr}\begin{array}{l}\text { Suffered } \\
\text { imprudent } \\
\text { practices }\end{array} & \text { from } \\
\text { banking }\end{array}$ & liquidated & $\begin{array}{l}\text { Chartered Accountants: } \\
\text { Grant Thornton Camelsa }\end{array}$ \\
\hline Trust Bank & 1996 & 2004 & $\begin{array}{l}\text { Non -performing loans } \\
\text { and poor corporate } \\
\text { governance structures }\end{array}$ & $\begin{array}{l}\text { Assets } \\
\text { incorporated } \\
\text { into a new } \\
\text { bank }\end{array}$ & $\begin{array}{l}\text { Accountant: } \\
\text { KPMG }\end{array}$ \\
\hline $\begin{array}{ll}\text { CFX } & \text { Bank } \\
\text { Limited } & \end{array}$ & 2002 & 2004 & $\begin{array}{l}\text { Serious liquidity and } \\
\text { profitability challenges }\end{array}$ & $\begin{array}{l}\text { Merged } \\
\text { with another } \\
\text { bank }\end{array}$ & $\begin{array}{l}\text { Accountants:Enerst and } \\
\text { Young }\end{array}$ \\
\hline $\begin{array}{l}\text { ReNaissance } \\
\text { Merchant } \\
\text { Bank (RMB) }\end{array}$ & & 2011 & $\begin{array}{lr}\text { Gross violation } & \text { of } \\
\text { banking laws and } \\
\text { regulations such } & \text { as } \\
\text { systematic abuse } & \text { of } \\
\text { depositors' funds } & \\
\end{array}$ & $\begin{array}{l}\text { Still under } \\
\text { curatorship }\end{array}$ & $\begin{array}{l}\text { Grant Thornton Camelsa } \\
\text { Chartered Accountants }\end{array}$ \\
\hline Royal Bank & 2002 & 2004 & $\begin{array}{l}\text { Non performing insider } \\
\text { loans } \\
\text { mismanagement }\end{array}$ & $\begin{array}{l}\text { Assets } \\
\text { incorporated } \\
\text { into a new } \\
\text { bank }\end{array}$ & $\begin{array}{l}\text { Accountants: Waterhouse } \\
\text { Coopers }\end{array}$ \\
\hline Barbican Bank & 2002 & 2004 & $\begin{array}{l}\text { Imprudent banking } \\
\text { practices }\end{array}$ & $\begin{array}{l}\text { Assets } \\
\text { incorporated } \\
\text { into a new } \\
\text { bank }\end{array}$ & $\begin{array}{l}\text { Accountants- } \\
\text { Waterhouse Coopers }\end{array}$ \\
\hline Time Bank & 1997 & 2004 & $\begin{array}{l}\text { Poor corporate } \\
\text { governance and weak } \\
\text { management systems }\end{array}$ & $\begin{array}{l}\text { Forced to } \\
\text { reform } \\
\text { operations }\end{array}$ & $\begin{array}{l}\text { Accountants: Waterhouse } \\
\text { Coopers }\end{array}$ \\
\hline
\end{tabular}

The above table shows some of the financial institutions which were placed under curatorship and the results indicate how curatorship has not assisted them.

\section{Key Findings}

4.1 Curatorship paradox

With the exception of Royal Bank Zimbabwe Limited and Trust Bank Corporation most of the financial institutions previously placed under the management of a curator are currently not in operation or at least not in 
the original form. Even the two banks mentioned above the curatorship ghost still haunt them, depositors are still not confident to do business with them. It is important to note that in Zimbabwe curatorship has never truly embraced as a solution that it is meant to be, primarily because it is designed for inherently unpopular purpose. Curatorship has become symbolic with financial loss in all its conceivable forms-temporary loss, permanent loss, loss of value, loss of time and loss of momentum. The above facts indicate how corporate governance can be short changed when financial institutions are place under curator.

\subsection{Profession of curators}

In all the cases above accountants were appointed to be curators. The issue that only lawyers and accountants are the only ones who can turn around financial institutions or companies in crisis cannot be left unchallenged. There are also other competent professionals who can team up with them or equally do better. There are corporate governance issues in the appointment of these professionals.

\subsection{Supervision of curators}

There is inadequate supervision of these curators by regulatory authorities, they have excessive power, they write reports to those who have appointed them and whether to extend their period with a financial institution is within their prerogative according to the Banking Act in Zimbabwe. Though they are professionals in their areas, there is a possibility of extending the curatorship period so that they can be paid more. Checks and balances are not enough in their work, I have never heard a situation where a curator was fired because of incompetence, whether they liquidate an institution in the first six months or extent the curatorship they are always correct.

\subsection{Curatorship is a booming business for curators}

The banking crisis in Zimbabwe spells good business for the curators they rake millions of dollars, the prerogative is theirs according to the Reserve Bank Act(RBZ) to extend the period a financial institution should be under curatorship or to liquidate the institution whichever way they are paid. It can also be noted that in most cases curators overcharge for their services and sometimes the money they charge if ejected into the institution it will recapitalise the organisation and resuscitate it. For example in the ReNaissance Merchant Bank (RMB) and his Grant Thornton Auditors team, they charged US\$630 316 in fees in the months between July and September 2011 according to Business Digest. The amount was going to be paid from depositors' funds. One important issue insiders in RMB questioned, was the continuous presence of auditors after a curator have been appointed and the external auditors were charging large sums of money and there were being paid from depositors' funds locked at RMB. Such an amount of money could have been used to resuscitate the financial institution in trouble. Curators charges exorbitant professional fees and hourly rates. Apart from paying huge fees to curators, distressed banks also have to pay millions of dollars in legal fees as the curator is entitled to hire lawyers to assist in chasing up delinquent debtors. These issues boil down to poor corporate governance practices by those who appoint curators and the curators.

\subsection{Poor corporate governance}

For all the banks placed under curatorship there is a common denominator or thread in all directors or founders of these financial institutions such as mismanagement of these institutions through imprudent banking practices, gross violation of banking laws and regulations such as systematic abuse of depositors' funds, non performing insiders' loans among others. A generally poor corporate governance and weak management systems by directors or founders of the financial institutions who would rob the institutions they have founded by misusing depositors' funds buying luxuries such as expensive houses and cars among others.

\section{Conclusion}

The study examined how corporate governance issues can be compromised when placing financial institutions under curatorship and how appointed curators can also compromise corporate governance when dealing with the affairs of a financial institution. The study also examine founders of financial institutions rob depositors funds of institutions they have started. The study shows that curatorship in Zimbabwe has failed to truly embrace as a solution it was meant to be, because it was designed for inherently unpopular purposed and the appetite for placing financial institutions under curatorship have been high giving reasons that they are protecting depositor's funds but in the above cases depositors had not gained much from the liquidations and mergers which had taken place.

Results of this study show that curatorship is booming business for accounting firms; the more the financial institutions are distressed the more they get their jobs and rake millions of the depositors' funds with their friends' lawyers whom they will appoint to chase debts. This indicates to a certain extend that when curators are appointed to run the affairs of a distressed financial institution they are concerned with their payments rather than bringing the company to life as indicated in the table above, a number of financial institutions were placed 
under curatorship and most of them excepted a few were either liquidated or failed return to original form.

The study also shows that regulatory authorities placed financial institutions under curatorship which did not have a chance to be resuscitated but they went on to place them under curatorship wasting depositors' money and enriching curators instead of cancelling the licence and apply to the High Court for placement of the institution under liquidation.

The other issue is that in most cases where financial institutions were placed under curatorship the regulatory authorities' response was reactive rather than proactive. Furthermore none of directors who have misused depositors' funds have been jailed.

Results also indicates that 2003/2004 financial crisis there was a shortage of curators and as a result the available curators, the well-known ones were only four but many financial institutions were facing challenges that time, they were overwhelmed with their work and their performance was unsatisfactory, recommending these institutions for liquidation and moving to another financial institution and rake millions of dollars without doing a thorough job. The issue suggest that curators overlooked the very basic requirements of good governance.

An implied conclusion from the case studies reviewed above, is that curatorship did not benefit the beneficiaries, that is, depositors, financial institutions, shareholders and others instead it benefited the curators themselves they enriched themselves instead of helping institutions under distress. The regulatory authorities placed under curatorship institutions which were insolvent instead of cancelling their licences and apply to the High Court for the institution to be placed under liquidation. It can be noted that the country's general economic standing affects good corporate governance as it will manifests itself in several ways, public officials often fail to distinguish between public and private resources and private sector is often associated with excessive greed, conspicuous consumption and "get rich -quick" schemes as in the case of 2003/2004 banking crisis where the Zimbabwean economy was in recession affecting the performance of financial institutions and those who were supposed to help them. Finally can be concluded that the curators need more curatorship than the financial institutions they try to help.

\section{References}

Companies' Act Chapter 28:01 Section 318

Davis, K 2003, 'Financial reform in Australia', in MJB Hall (ed), The international handbook on financial reform, Edward Elgar Publishing, Aldershot, Hants,UK

Garrant,B (1997)The Fish Rotis From the Head Harper, Collins Business

Greuning H and Bratanovic,S.B.(2003) Analyzying and Managing Banking Risk.A Framework for Assessing Corporate Governance and Financial Risk,Second Edition, The World Bank, Washington D.C.New York

Hamel (1998) Hampel Report on Corporate Governance, Gee Publishing Company

Johnson G.and Scholes K. (1997) Exploring Corporate Strategy: Text and Cases, Prentice Hall.

McGregor L.(2000)The Human Face of Corporate Governance,Palgrave,Hampshire,New York

Mesnard, M., 2005, The OECD Guidelines on Corporate Governance of State-Owned Enterprises, Kiev.

OECD (Organization for Economic Cooperation and Development), 1999, OECD Principles of Corporate Governance. Paris.

Otobo, E. E., 2000, “Contemporary External Influences on Corporate Governance: Coping with the Challenges in Africa." A Paper prepared for the African Development Bank as a background paper for its Africa Development Report 2001 on Fostering Good Governance in Africa.

Reserve Bank of Zimbabwe Act, Acts 5/1999, 22/2001

Soros, G (1998)The Crisis of Global Capitalism, Little Brown and Company 